\title{
1,2-Benzenedithiol and Toluene-3,4-dithiol Arsenic(III) Complexes-Synthesis, Structure, Spectroscopic Characterization and Toxicological Studies
}

\author{
Monika Lyczko* , Krzysztof Lyczko®, Agnieszka Majkowska-Pilip $₫$ and Aleksander Bilewicz \\ Institute of Nuclear Chemistry and Technology, Dorodna 16, 03-195 Warsaw, Poland; \\ k.lyczko@ichtj.waw.pl (K.L.); a.majkowska@ichtj.waw.pl (A.M.-P.); a.bilewicz@ichtj.waw.pl (A.B.) \\ * Correspondence: m.lyczko@ichtj.waw.pl
}

Received: 3 October 2019; Accepted: 24 October 2019; Published: 26 October 2019

\begin{abstract}
A new group of arsenic(III) complexes with bidentate S,S-donor ligands, 1,2-benzenedithiol $\left(\mathrm{Ph}(\mathrm{SH})_{2}\right)$ and toluene-3,4-dithiol $\left(\mathrm{MePh}(\mathrm{SH})_{2}\right)$, were synthesized. The use of arsenic(III) iodide and bromide promoted the formation of neutral complexes (1-4) with the general formula AsX $\left(\mathrm{LS}_{2}\right)(\mathrm{X}=\mathrm{I}$ or $\mathrm{Br}, \mathrm{L}=\mathrm{MePh}$ or $\mathrm{Ph})$. The crystal structures of these compounds were determined using single-crystal X-ray diffraction (scXRD). Unlike other arsenic(III) complexes, $\mathrm{AsBr}\left(\mathrm{PhS}_{2}\right)$ complex (2) was found to crystallize with a rare 13 molecules in the asymmetric unit. The compounds were also characterized by conventional physico-chemical techniques (Fourier transform infrared (FT-IR) spectroscopy, ultraviolet-visible (UV-Vis) spectroscopy, nuclear magnetic resonance (NMR), high-performance liquid chromatography (HPLC), elemental analysis (EA) and electrospray ionization-mass spectrometry (ESI-MS)). The results from structural and spectroscopic studies were supported by DFT calculations using the B3LYP/LANL2DZ and (or) 6-31+G(d,p) approaches. The cytotoxicity of these complexes was estimated for human acute promyelocytic leukemia cell line (NB4). They exhibited remarkable cytotoxicities after $48 \mathrm{~h}$ of treatment with $\mathrm{IC}_{50}$ equal to about $10 \mu \mathrm{M}$ and $40 \mu \mathrm{M}$ for complexes with 1,2-benzenedithiolato and toluene-3,4-dithiolato ligand, respectively. Their toxicity was lower than that of commonly used chemotherapeutic $\mathrm{As}_{2} \mathrm{O}_{3}\left(\mathrm{IC}_{50}=1.4 \mu \mathrm{M}\right)$.
\end{abstract}

Keywords: arsenic(III) complexes; dithiols; crystal structure; DFT calculations; cytotoxicity; APL; NB4 cells

\section{Introduction}

Inorganic arsenic exhibits strong toxic properties and is classified by the International Agency for Research on Cancer and US Environmental Protection Agency as a human carcinogen. Arsenic causes huge cellular alterations via numerous pathways, such as induction of apoptosis, inhibition of proliferation, stimulation of differentiation, and inhibition of angiogenesis [1]. Although arsenic is highly toxic for humans, for years it has been employed in medicine to treat many diseases. The affinity of arsenic to sulphur atoms is of great importance for the development of new arsenic compounds, which are applicable in cancer therapy. Furthermore, the search for novel compounds possessing lower toxicity for patients compared with classic $\mathrm{As}_{2} \mathrm{O}_{3}$, which is currently used for the treatment of acute promyelocytic leukemia (APL) as well as other types of cancers, is desirable [2]. However, chronic exposure to arsenic or arsenic derivatives can also promote toxic effects, because similar mechanisms are responsible for both the therapeutic and toxic effects.

The $\mathrm{As}_{2} \mathrm{O}_{3}$ mechanism of action is complicated and leads to induction of apoptosis and partial differentiation of cells. The binding of trivalent arsenic to crucial thiol groups in proteins may inhibit 
biochemical events and cause toxicity. On the other hand, binding arsenite at non-essential sites may involve a detoxication mechanism. Reports have shown that an acute toxicity of arsenic is related to its chemical form and oxidation state. Inorganic arsenic in its oxidation state +5 is metabolized by the process of a two-electron reduction to arsenic(III), and then by an oxidative methylation to pentavalent organic arsenic [3].

Trivalent arsenicals readily react with thiol-containing molecules. Unfortunately, specific functional groups within enzymes, receptors or coenzymes, such as thiols or vicinal sulfhydryls, have a major role in the activity of these molecules which results in the attachment of arsenic(III) causing reduction in their biological activity [3,4].

Glutathione (GSH) plays an important role in the metabolism of arsenic in human tissues by forming stable complexes with arsenic. The sensitivity of cells toward arsenic compounds is related to the level of GSH in the cell [5,6]. Therefore, cancer cells that contain low levels of GSH are arsenic sensitive, in contrast, those with higher GSH concentration, such as lung and liver cancer cells, are more arsenic resistant [7]. Therefore, GSH in human cells inhibit arsenic(III) toxicity.

There are many arsenic(III) complexes possessing organic compounds, which involve two $\mathrm{S}$ donor atoms, such as dithiocarbamates, where arsenic is bound bidently or monodently [8-14]. The bidentate sulphur donor ligands can form four- [8,14,15], five- [16-18], six- [17,18] and even seven-membered [17,19] chelate rings with arsenic(III) ion. Furthermore, although scarce, homoleptic arsenic(III) compounds with monodently acting S donor ligands have been structurally characterized [17,20-23].

Recently, the synthesis and structure of chloro-arsenic(III) compounds with toluene-3,4-dithiolato and 1,2-benzenedithiolato ligands have been published [24]. However, Kisenyi et al. were the first to report this compound over 30 years ago [25]. Besides these chloro-arsenic(III) species the simple salts of $\left[\mathrm{As}\left(\mathrm{MePhS}_{2}\right)\right]\left[\mathrm{MCl}_{4}\right](\mathrm{M}=\mathrm{Al}, \mathrm{Ga})$ and $\left[\mathrm{As}\left(\mathrm{PhS}_{2}\right)_{2}\right]\left[\mathrm{NEt}_{4}\right]$ have also been presented $[24,26]$.

In the case of toluene-3,4-dithiol some dithiocarbamate and dithiophosphate derivatives of arsenic(III) compounds $\left[\mathrm{As}\left(\mathrm{S}_{2} \mathrm{CNR}_{2}\right)\left(\mathrm{MePhS}_{2}\right)\right.$ and $\left.\mathrm{As}\left(\mathrm{S}_{2} \mathrm{P}(\mathrm{OmTol})_{2}\right)\left(\mathrm{MePhS}_{2}\right)\right]$ are also structurally characterized $[13,27]$.

Therefore, arsenic complexes with dithiols as well as $\mathrm{As}_{2} \mathrm{O}_{3}$ could be an interesting cytostatic agents for tumor treatment. Since dithiols form complexes with As(III) via two sulphur atoms, the last site could be occupied by any anion or used as a convenient linker with the suitable biomolecule. This would allow the conjugation of an appropriate compound that could, for example, be a guiding molecule to specific cancer cells. This type of complexation would be also helpful for their application in targeted radionuclide therapy. Recently, due to the development of personalized medicine radioisotopes of arsenic, they are of considerable interest to the field of nuclear medicine with unique nuclear properties making them well-suited for novel theranostic radiopharmaceuticals. The decay properties of arsenic radionuclides are ideal for a variety of diagnostic and therapeutic applications. Radionuclides ${ }^{77} \mathrm{As}\left(\beta^{-}\right.$ emitter with $\mathrm{T}_{1 / 2}=38.83 \mathrm{~h}$ and energy $\mathrm{E}_{\beta \max }=0.683 \mathrm{MeV}$ ) and ${ }^{72} \mathrm{As}$ (positron emitter with $\mathrm{T}_{1 / 2}=26.0 \mathrm{~h}$ and energy $\mathrm{E}_{\gamma}=511,834 \mathrm{keV}$ ) form an ideal theranostic pair. These radionuclides, when attached to an appropriate biomolecule such as a monoclonal antibody, can be used in cancer diagnosis, plan treatment, and provide effective therapy [28]. In this work we present arsenic(III) complexes with selected dithiols for possible therapeutic applications. After full structural characterization, the cytotoxicity of the obtained complexes for acute promyelocytic leukemia cells (NB4) was investigated and compared with $\mathrm{As}_{2} \mathrm{O}_{3}$.

\section{Results and Discussion}

\subsection{Synthesis}

Four new arsenic(III) complexes were obtained as orange (1 and 3) or yellow (2 and 4) crystals in moderate yields (40-57\%) via the reaction of two different dithiol ligands (1,2-benzenedithiol $\left(\mathrm{Ph}(\mathrm{SH})_{2}\right)$ and toluene-3,4-dithiol $\left.\left(\mathrm{MePh}(\mathrm{SH})_{2}\right)\right)$ and arsenic(III) compounds $\left(\mathrm{AsBr}_{3}\right.$ and $\left.\mathrm{AsI}_{3}\right)$ in refluxing chloroform solutions. Scheme 1 shows a simplified reaction pathway of the prepared 
compounds. The synthesis of these compounds was inspired by the methods described in ref [25]. All complexes crystalized quickly, typically overnight and their structures confirmed using common methods (single-crystal X-ray diffraction (scXRD), elemental analysis (EA), electrospray ionization-mass spectrometry (ESI-MS), Fourier transform infrared spectroscopy (FT-IR), ultraviolet-visible (UV-Vis) spectroscopy, nuclear magnetic resonance (NMR)). High-performance liquid chromatography (HPLC) reference peaks were also determined for every compound (Figure 1). The retention times of 1-4 differ from the free dithiols, so the reaction progress is easy to control via this simple method.

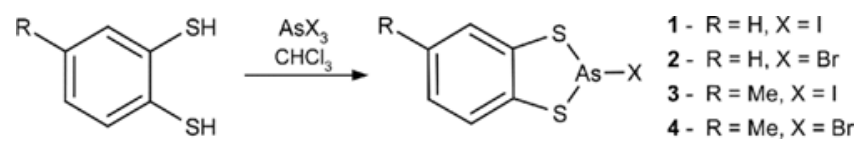

Scheme 1. Synthesis of dithiolato arsenic(III) compounds.

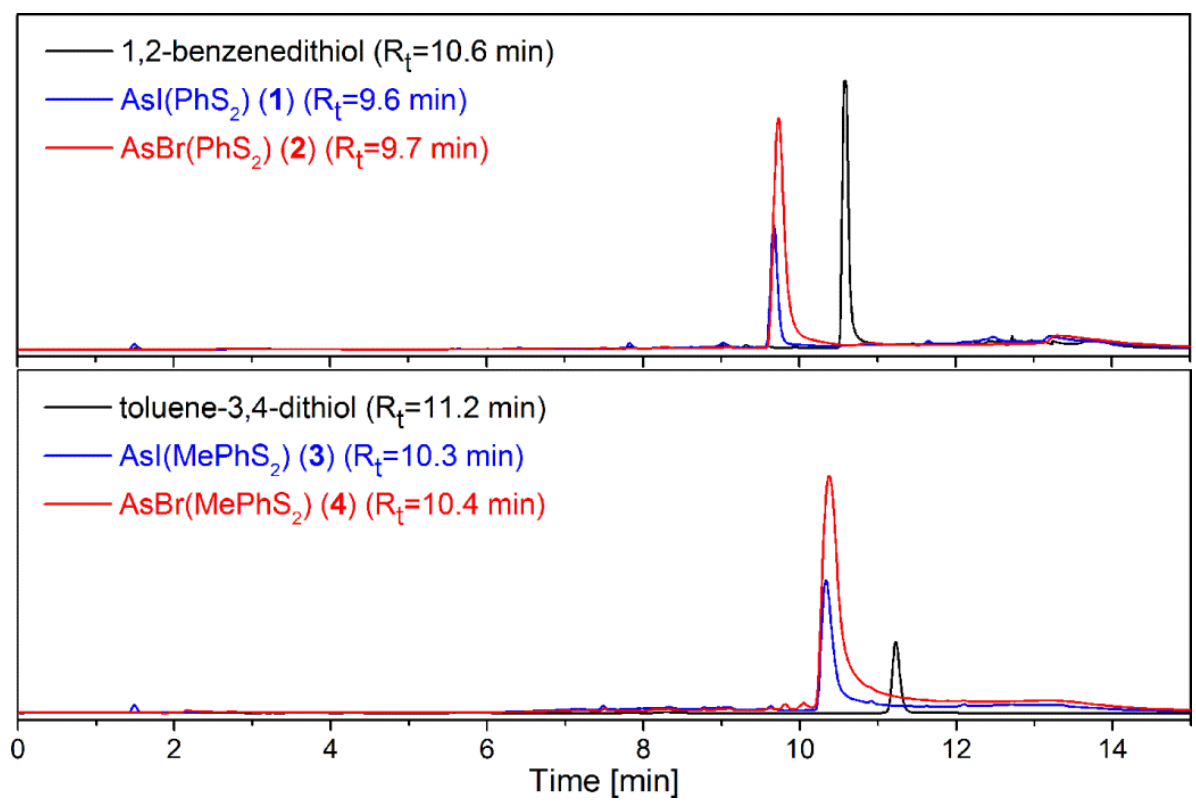

Figure 1. The high-performance liquid chromatography (HPLC) chromatograms of the obtained arsenic compounds.

\subsection{Description of the Prepared Complexes Molecular and Crystal Structures}

The main bond lengths and angles derived from measurements and calculations of compounds 1-4 are shown in Table 1, whereas the molecular structure of these compounds are presented in Figure 2. In each individual molecule of the studied complexes the arsenic atom is three coordinate, being bound to a halogen atom and chelated to two sulphur atoms belonging to the dithiolato ligand. The arsenic(III) coordination sphere can therefore be described as distorted tetrahedral, with one corner occupied by the active $4 s^{2}$ lone electron pair. The mean As-S bond length (2.21 $\AA$ ) in 1-4 is about 0.26 and $0.50 \AA$ shorter than the mean As-Br (2.47 $\AA$ ) and As-I (2.71 $\AA$ ) distances, respectively. All determined bond lengths are similar to the corresponding distances in other arsenic(III) compounds $[16,17,29]$. Three angles with the apex on the arsenic atom changing in range $93^{\circ}-106^{\circ}$ are less than the normal tetrahedral angle $\left(109.5^{\circ}\right)$ showing the dominant position of the lone electron pair on the central atom. The S1-As1-S2 bite angles (mean value of $93.2^{\circ}$ ) are typical of this type of five-membered chelate ring $[17,24]$. All studied compounds have a non-planar chelate ring (envelope geometry) with the arsenic atom lying approximately $0.22,0.31$ (mean value from 13 molecules), 0.32 and $0.33 \AA$ out of plane formed by the S1, C1, C2 and S2 atoms for 1-4, respectively. 
Table 1. Selected bond lengths $(\AA)$ and angles $\left({ }^{\circ}\right)$ of complexes 1-4 obtained from experiment and DFT calculations (B3LYP/6-31+G(d,p);LANL2DZ) $(X=\mathrm{I} 1$ (1 and 3) and Br1 (2 and 4)). * In the case of 2 the experimental data are given as mean values from 13 molecules.

\begin{tabular}{ccccccccc}
\hline Compound & \multicolumn{2}{c}{$\mathbf{1}$} & \multicolumn{2}{c}{$\mathbf{2}$} & \multicolumn{2}{c}{3} & \multicolumn{2}{c}{$\mathbf{4}$} \\
\hline & Exp. & Calc. & Exp. $^{*}$ & Calc. & Exp. & Calc. & Exp. & Calc. \\
\hline Bond lengths & & & & & & & & \\
As1-S1 & $2.218(1)$ & 2.252 & $2.212(3)$ & 2.243 & $2.216(1)$ & 2.250 & $2.208(1)$ & 2.245 \\
As1-S2 & $2.227(1)$ & 2.252 & $2.210(3)$ & 2.246 & $2.212(1)$ & 2.252 & $2.205(1)$ & 2.242 \\
As1-X & $2.730(1)$ & 2.700 & $2.467(1)$ & 2.421 & $2.699(1)$ & 2.704 & $2.469(1)$ & 2.423 \\
S1-C1 & $1.764(5)$ & 1.779 & $1.759(9)$ & 1.778 & $1.752(4)$ & 1.779 & $1.757(2)$ & 1.779 \\
S2-C2 & $1.763(4)$ & 1.779 & $1.759(9)$ & 1.779 & $1.762(5)$ & 1.779 & $1.761(2)$ & 1.779 \\
\hline Angles & & & & & & & & \\
X-As1-S1 & $98.69(4)$ & 103.27 & $100.81(7)$ & 101.91 & $103.32(4)$ & 103.40 & $102.96(1)$ & 101.66 \\
X-As1-S2 & $106.10(4)$ & 103.29 & $100.83(7)$ & 101.57 & $101.31(4)$ & 103.22 & $100.86(1)$ & 101.76 \\
S1-As1-S2 & $92.97(5)$ & 92.09 & $93.20(9)$ & 93.10 & $93.29(5)$ & 92.15 & $93.38(2)$ & 93.22 \\
\hline
\end{tabular}
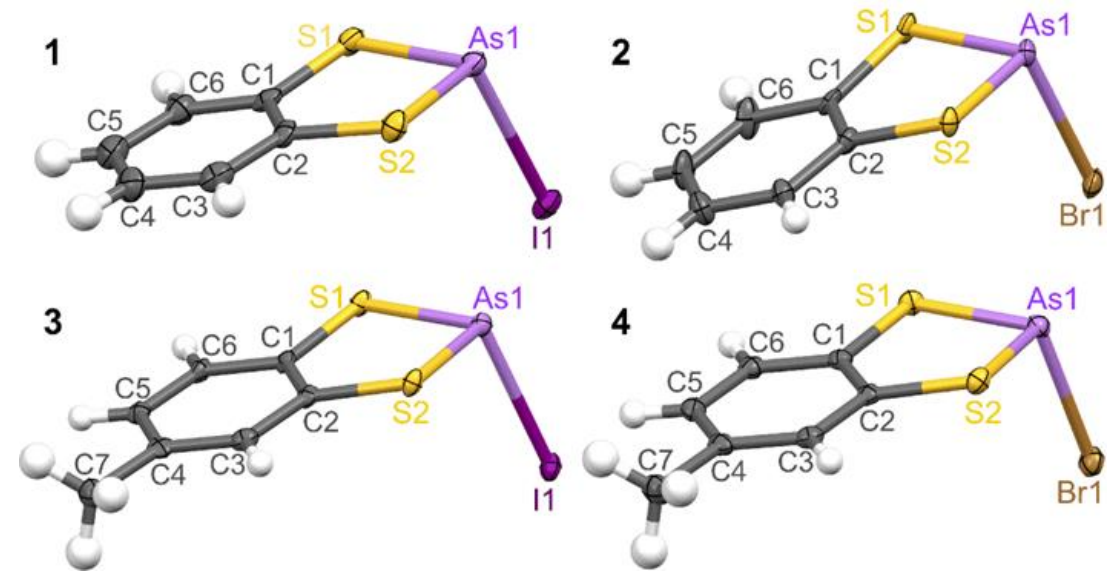

Figure 2. Molecular structure of compounds 1-4.

The main motif in all presented crystal structures is a dimeric fragment $\left[\mathrm{AsX}\left(\mathrm{LS}_{2}\right)\right]_{2}(\mathrm{X}=\mathrm{I}$ or $\mathrm{Br}, \mathrm{L}$ $=\mathrm{MePh}$ or $\mathrm{Ph}$ ). Within these dimeric units the molecules are stabilized through four-center $[\mathrm{AsX}]_{2}$ interactions. Compound $\mathbf{1}$ has a crystal structure consisting of chains along the crystallographic axis formed by the repetition of one $\left[\mathrm{AsI}\left(\mathrm{PhS}_{2}\right)\right]_{2}$ fragment (Figure 3) which is stabilized through intra-dimer

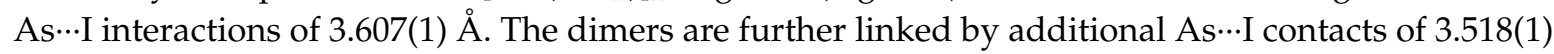
$\AA$ A. All these intermolecular As $\cdots$ I contacts are shorter than the sum of the van der Waals radii of arsenic and iodine (3.83 $\AA$ ) [30]. The shortest contacts between neighboring chains in $\mathbf{1}$ correspond to the

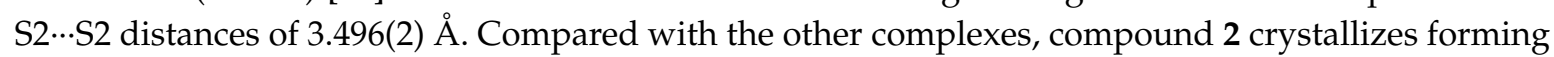
a surprisingly large unit cell which consists of 13 crystallographically independent molecules in the asymmetric unit (Table 2 and Figure 4). Moreover, according to the Cambridge Structural Database, there is a relatively small number of structures with such a high number of molecules per asymmetric unit ( $\left.Z^{\prime}\right)$ with only 30 different structures for $Z^{\prime} \geq 13$ reported to date [31]. The remaining compounds possess only one molecule in the asymmetric part. Similarly to compound 2 , its chlorido analogue also contains a rare high $Z^{\prime}$ structure with 17 molecules in the asymmetric unit [24]. The 13 molecules in compound 2 form 7 crystallographically different dimers through intra-dimer As $\cdots B$ Br contacts in the range 3.380(1)-3.586(1) $\AA$. Only one of these units is constructed from two of the same molecules containing As1B atoms. All dimers are held together by additional As $\cdots \mathrm{Br}$ distances remaining in the range 3.465(2)-3.656(2) $\AA$. These inter-dimer As $\cdots B$ Br contacts are usually slightly longer than the intra-dimer distances. Nevertheless, all aforementioned distances are shorter than the sum of the

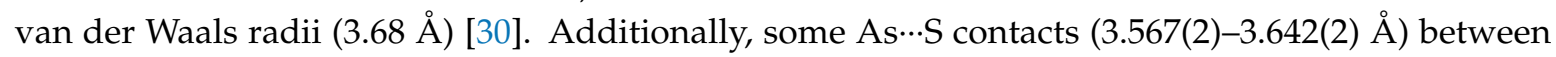


molecules of compound 2 are very close to the sum of the respective van der Waals radii (3.65 $\AA$ ) [30]. The molecular packing in compounds 3 and 4 is essentially the same and consists of dimeric units

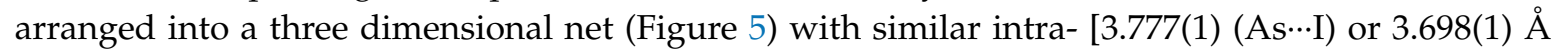

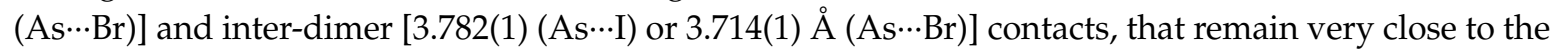
sum of the respective van der Waals radii [30]. In addition, the molecules are stabilized by S...C contacts of 3.499(6) and 3.546(2) $\AA$ (for compounds 3 and 4, respectively) between the adjacent chelating rings. The shortest distances between neighboring arsenic atoms in 1 (3.922(1) $\AA$ ) and 2 (mean 3.945(2) $\AA$; range 3.847(2)-4.004(2)) lay outside the dimers. By contrast, the shortest As $\cdots$ As contacts for compound $3(4.645(1) \AA)$ and $4(4.376(1) \AA)$ are placed within the dimeric entities. All these distances fall beyond twice the van der Waals radius of arsenic (3.70 $\AA$ ) [30].

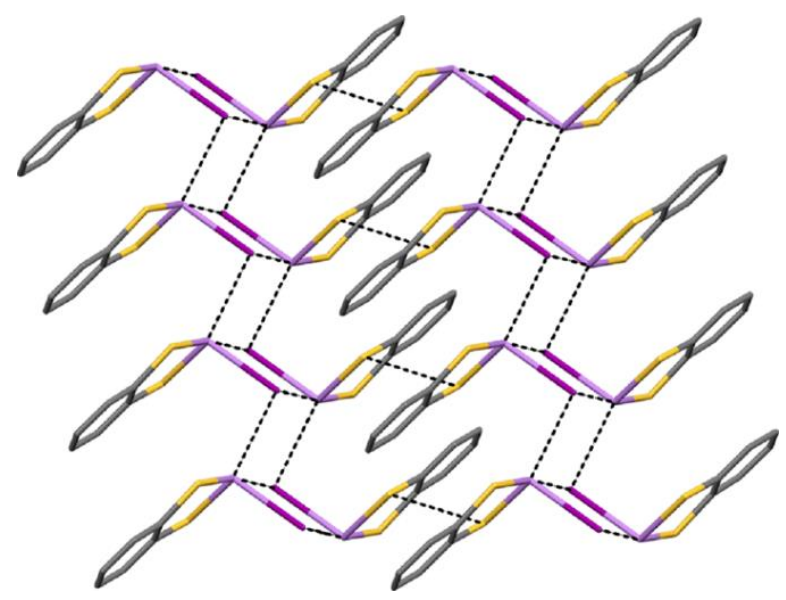

Figure 3. Fragment of the crystal structure of $\mathbf{1}$ showing some intermolecular interactions between $\operatorname{AsI}\left(\mathrm{PhS}_{2}\right)$ molecules.

Table 2. Crystallographic data and structure refinement parameters of the compounds 1-4.

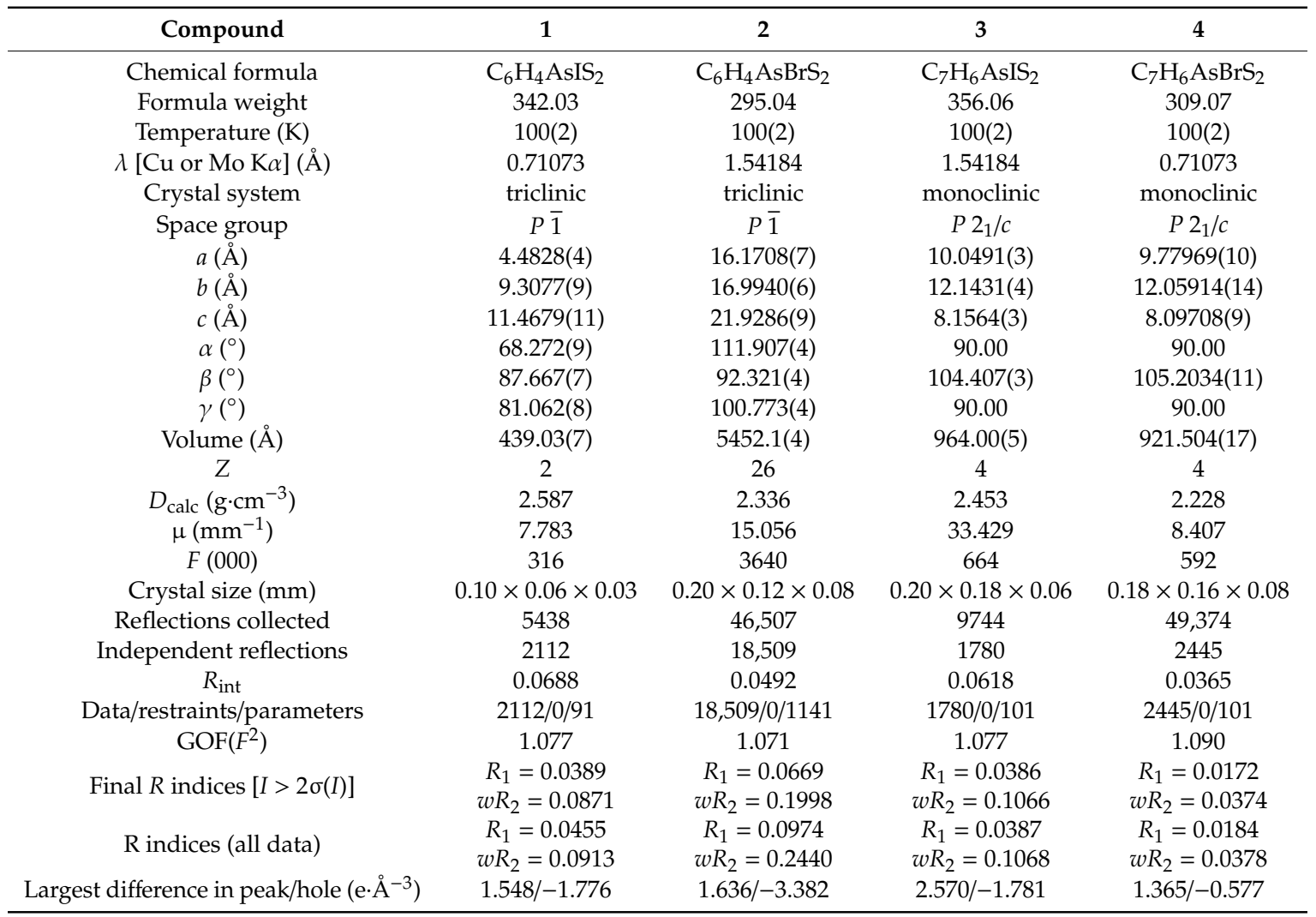




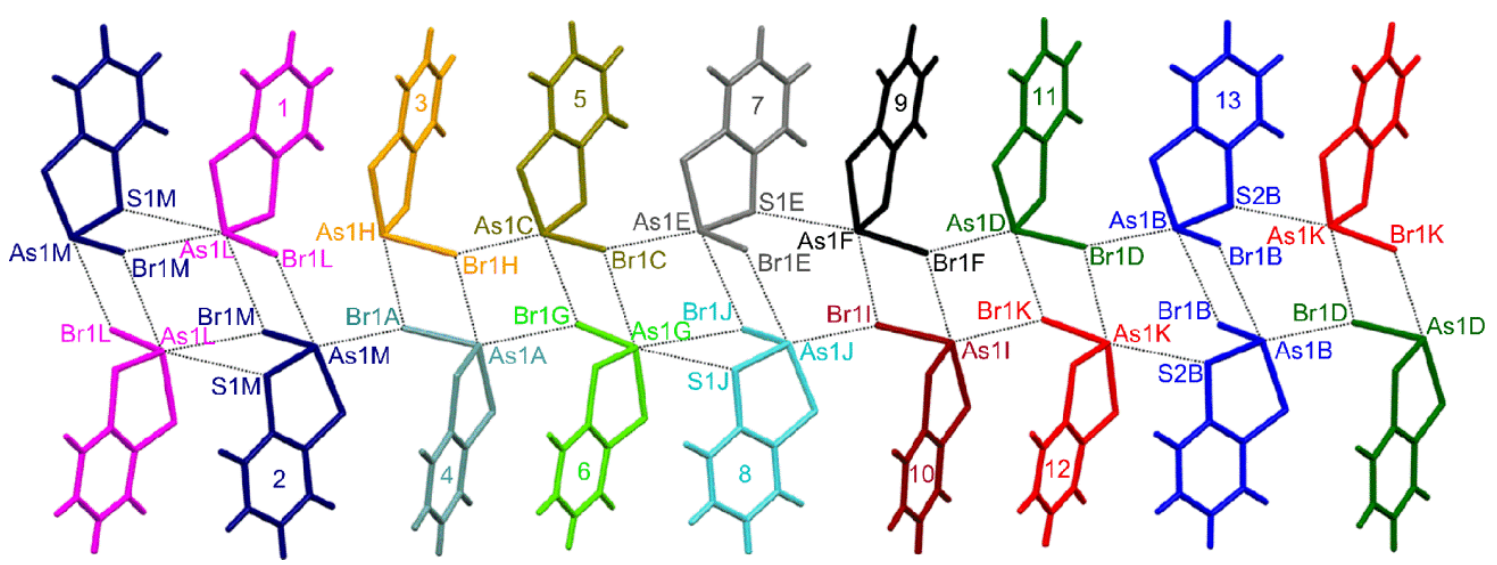

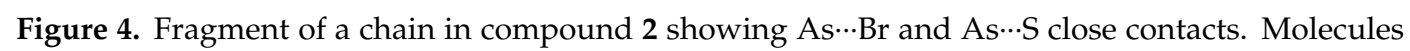
are presented in different colors to highlight the 13 crystalographically independent molecules in the asymmetric unit.

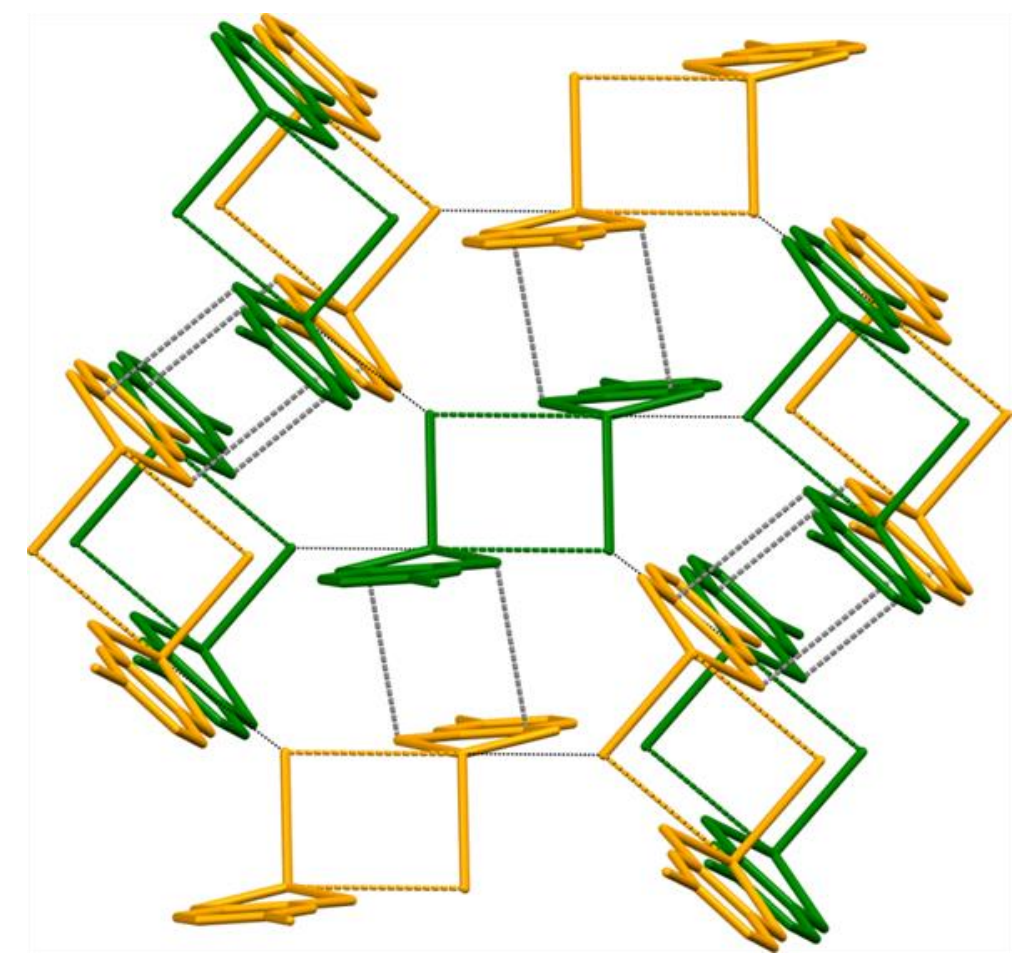

Figure 5. Fragment of the crystal structure of 3 and 4 showing some intermolecular interactions.

\subsection{DFT Modelled Molecular Structures}

The geometric parameters of the presented arsenic(III) compounds were also optimized by means of various basis sets within B3LYP functional. The smallest mean absolute deviation (MAD) values determined for the chosen bond lengths and angles indicate that satisfactory correlations between the experimental and calculated structures for all compounds are obtained using a LANL2DZ basis set for iodine atom and $6-31+\mathrm{G}(\mathrm{d}, \mathrm{p})$ basis set for the remaining elements (see Tables $\mathrm{S} 1-\mathrm{S} 4)$. Satisfactory results are also otbained using 6-31G(d,p) and LANL2DZ basis sets for compounds 1 and 3 or $6-31++G(d, p)$ basis set for compunds 2 and 4 . The most important bond lengths and angles for studied complexes derived from the crystal structure are in a good agreement with calculations presented in Table 1 and Figure 6. In all cases the differences between experimental and modelled bond distances are no longer than $0.05 \AA$. The largest differences (approximately $0.05 \AA$ ) are observed for As-Br bond lengths. 


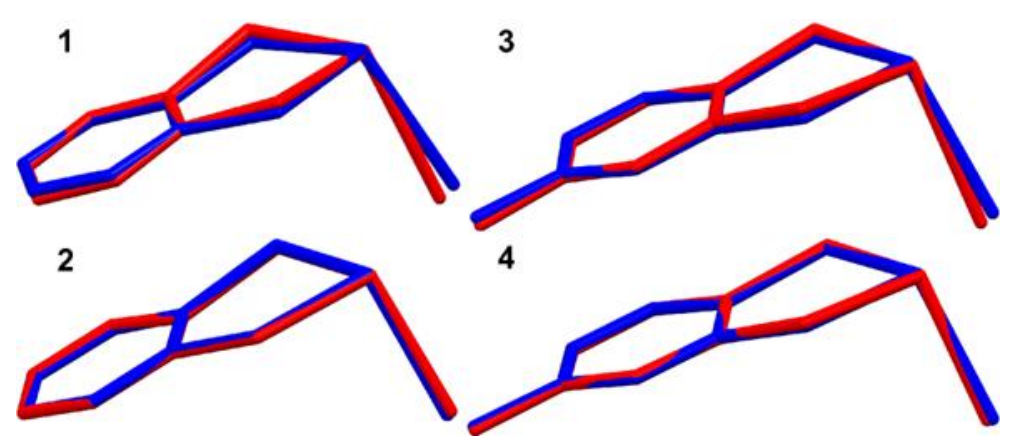

Figure 6. Graphical presentation showing the overlay of the molecular structures derived from DFT calculation (red) and experiment (blue) for $\mathrm{AsI}\left(\mathrm{PhS}_{2}\right)$ (1) $(\mathrm{RMSD}=0.146 \AA), \mathrm{AsBr}\left(\mathrm{PhS}_{2}\right)$ (2) $(\mathrm{RMSD}=0.042 \AA), \mathrm{AsI}\left(\mathrm{MePhS}_{2}\right)(3)(\mathrm{RMSD}=0.111 \AA), \operatorname{AsBr}\left(\mathrm{PhS}_{2}\right)(4)(\mathrm{RMSD}=0.041 \AA)$.

\subsection{Spectroscopic Characterization of the Arsenic(III) Compounds}

The infrared absorption spectra of the studied complexes were compared with the spectra obtained for the free dithiol ligands (Figures S1-S6). The formation of dithiolato arsenic(III) compounds are confirmed through the obtained infrared (IR) spectra by the complete removal of the broad S-H stretching vibrations located at around $2538 \mathrm{~cm}^{-1}$ present in the free ligands. Comparing the IR data, compounds $\mathbf{1}$ with $\mathbf{2}$, and $\mathbf{3}$ with $\mathbf{4}$ have very similar spectra with only slight shifts between equivalent bands. Almost the entire spectra are dominated by vibrations of the aromatic ring and $\mathrm{C}-\mathrm{H}$ bonds. The experimentally obtained IR spectra of complexes 1-4 were in good agreement with the calculated data (see Figures S2, S3, S5 and S6).

In general, UV-Vis spectra of the studied complexes display intense absorptions below $280 \mathrm{~nm}$, accompanied by a lower-intensity band at 370 and $375 \mathrm{~nm}$ for iodo or 331 and $336 \mathrm{~nm}$ for bromo species (Figure 7). An absorption maximum at $296 \mathrm{~nm}$ and a shoulder at about $290 \mathrm{~nm}$ are observed for pure toluene-3,4-dithiol and 1,2-benzenedithiol but not after complexation to arsenic(III). Changing the halogen atom from bromine to iodine for the respective dithiolato complex shifts the lower energy band by about $40 \mathrm{~nm}$ to higher wavelengths. Furthermore, the addition of a methyl group to 1,2-benzenedithiolato ligand contributes to only a slight shift of the band maximum of the corresponding complex to higher wavelengths. TD-DFT calculated absorption spectra of these compounds in a simulated solvent (dichloromethane) are in good agreement with experimental results (Figure S7). The data presented in Table 3 correspond to the major singlet excitations with the lowest energies. The polarizable continuum model (IEFPCM) was used to model solvation effects during calculations by means of B3LYP method. The calculated transitions are shown in Tables S5-S8. The frontier orbitals of $\mathbf{1}$, taken as representative examples for the studied compounds are presented in Figure 8 (compound $\mathbf{1}$ has very similar MO diagrams to $\mathbf{2}-\mathbf{4}$, see Figure S8). The HOMO and LUMO energy differences are equal to $3.84,4.33,3.73$ and $4.21 \mathrm{eV}$ for compounds 1-4, respectively. These energy gaps are higher by about $0.5 \mathrm{eV}$ for bromide bearing compounds. In addition, the presence of a methyl group on the bidentate ligand displays a slightly lower energy difference of about $0.1 \mathrm{eV}$, compared with the analogous complexes bereft of $\mathrm{CH}_{3}$ moiety. According to TD-DFT results, shown in Table 3, the lowest energy transitions, corresponding to the major bands above $300 \mathrm{~nm}$, involve mainly the promotion of an electron from HOMO to LUMO (for 1-4) and LUMO+2 (for 2 and 4). In lesser extent these absorptions are accompanied by $\mathrm{HOMO} \rightarrow \mathrm{LUMO}+1, \mathrm{HOMO}-1 \rightarrow$ LUMO and, additionally for $\mathbf{1}$ and 3, HOMO-2 $\rightarrow$ LUMO excitations. As shown in Table 4 the two highest occupied MOs of compounds 1-4 are the orbitals of dithiolato and halide ligands with the predominant contribution from the bidentate ligand. The HOMO-2 orbital is located primarily on the halide ion. The lowest occupied MO orbital displays a mixed As/halogen/bidentate ligand character with the highest contribution being from the arsenic atom. In turn, the next two LUMOs (LUMO+1 and LUMO+2) of all compounds are the orbitals of the dithiolato ligand and arsenic. Therefore, the lowest-lying electronic transitions 
of compounds 1-4 have mainly mixed ligand-to-metalloid (bidentate ligand $\rightarrow$ As) charge transfer and ligand-centered transitions involving dithiolato ligand. In addition, some contributions from ligand-to-ligand (bidentate ligand $\rightarrow$ monodentate ligand) and halide-to-metalloid (halide $\rightarrow$ As) charge transfers are also observed.

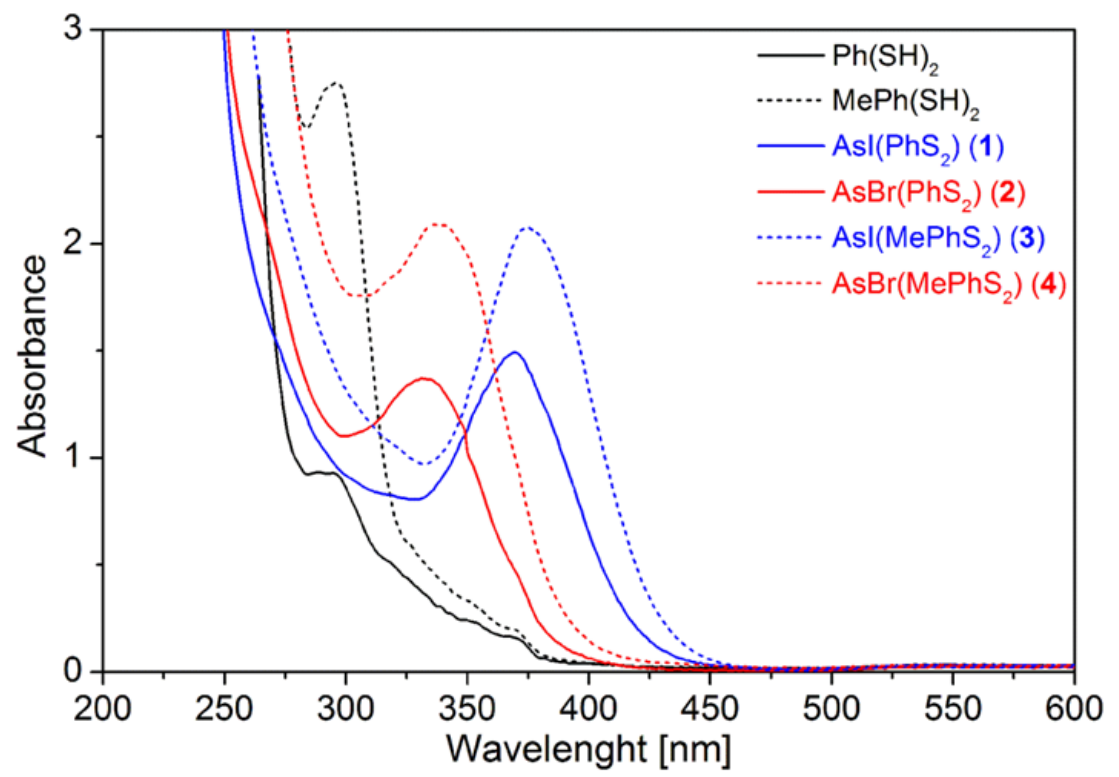

Figure 7. Ultraviolet-visible (UV-Vis) spectra of free dithiol ligands and their arsenic(III) compounds.

Table 3. The highest wavelength absorption data from experiments and calculations (TD-DFT) for the studied arsenic(III) compounds.

\begin{tabular}{|c|c|c|c|c|}
\hline \multirow{2}{*}{ Compound } & \multicolumn{3}{|l|}{ Calculated } & \multirow{2}{*}{$\begin{array}{c}\text { Experimental } \\
\lambda(\mathrm{nm})\end{array}$} \\
\hline & $\lambda(\mathrm{nm})$ & Oscillator Strength & Main Components & \\
\hline \multirow[t]{4}{*}{1} & 381.49 & 0.1485 & $\mathrm{H} \rightarrow \mathrm{L}(94.2 \%)$ & 370 \\
\hline & 355.05 & 0.0055 & $\mathrm{H}-1 \rightarrow \mathrm{L}(94.2 \%)$ & \\
\hline & 342.02 & 0.0086 & $\mathrm{H}-2 \rightarrow \mathrm{L}(98.7 \%)$ & \\
\hline & 332.22 & 0.0031 & $\mathrm{H} \rightarrow \mathrm{L}+1(95.6 \%)$ & \\
\hline \multirow[t]{6}{*}{2} & 345.16 & 0.0686 & $\mathrm{H} \rightarrow \mathrm{L}(88.4 \%)$ & 331 \\
\hline & & & $\mathrm{H} \rightarrow \mathrm{L}+2(9.6 \%)$ & \\
\hline & 310.46 & 0.0060 & $\mathrm{H}-1 \rightarrow \mathrm{L}(85.8 \%)$ & \\
\hline & & & $\mathrm{H} \rightarrow \mathrm{L}+1(8.7 \%)$ & \\
\hline & 301.80 & 0.0640 & $\mathrm{H} \rightarrow \mathrm{L}+2(84.6 \%)$ & \\
\hline & & & $\mathrm{H} \rightarrow \mathrm{L}(8.3 \%)$ & \\
\hline \multirow[t]{4}{*}{3} & 392.75 & 0.1447 & $\mathrm{H} \rightarrow \mathrm{L}(94.9 \%)$ & 375 \\
\hline & 358.86 & 0.0082 & $\mathrm{H}-1 \rightarrow \mathrm{L}(93.2 \%)$ & \\
\hline & 342.56 & 0.0079 & $\mathrm{H}-2 \rightarrow \mathrm{L}(98.6 \%)$ & \\
\hline & 338.15 & 0.0041 & $\mathrm{H} \rightarrow \mathrm{L}+1(95.6 \%)$ & \\
\hline \multirow[t]{6}{*}{4} & 354.59 & 0.0676 & $\mathrm{H} \rightarrow \mathrm{L}(89.2 \%)$ & 336 \\
\hline & & & $\mathrm{H} \rightarrow \mathrm{L}+2(9.0 \%)$ & \\
\hline & 314.95 & 0.0052 & $\mathrm{H}-1 \rightarrow \mathrm{L}(87.0 \%)$ & \\
\hline & & & $\mathrm{H} \rightarrow \mathrm{L}+1(5.2 \%)$ & \\
\hline & 308.52 & 0.0700 & $\mathrm{H} \rightarrow \mathrm{L}+2(84.7 \%)$ & \\
\hline & & & $\mathrm{H} \rightarrow \mathrm{L}(7.8 \%)$ & \\
\hline
\end{tabular}




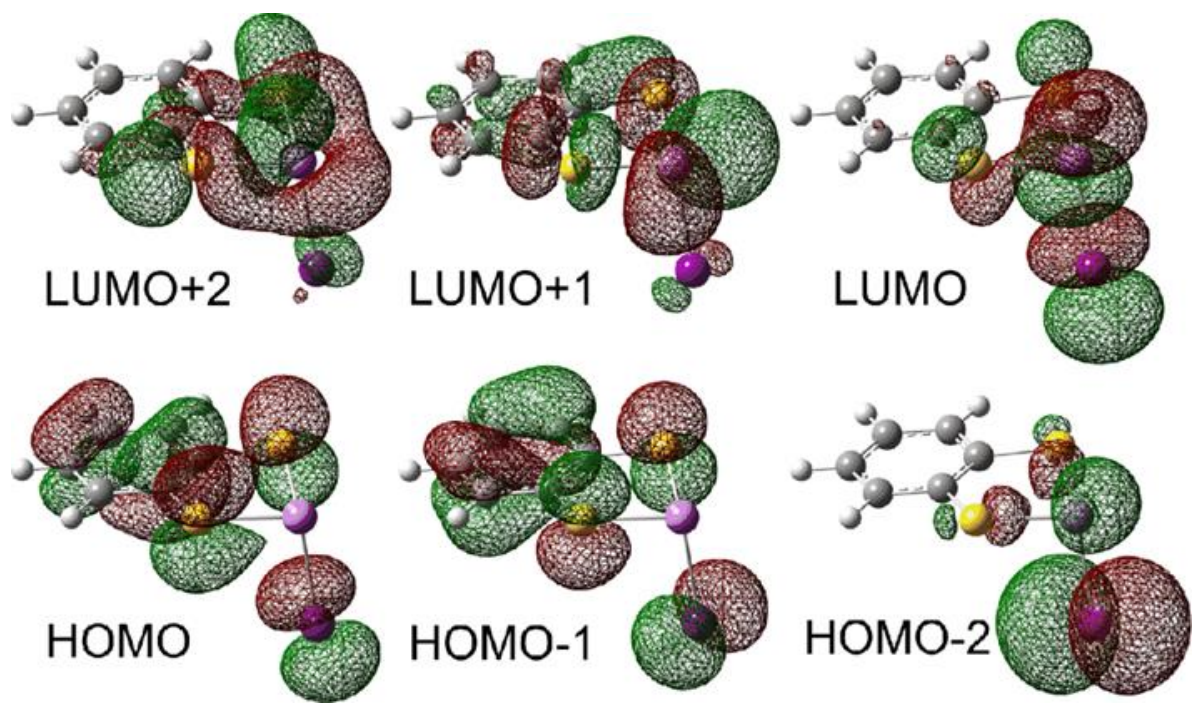

Figure 8. Orbital contours of the lowest energy transitions for $\mathbf{1}$ as representative of all studied compounds.

Table 4. DFT (B3LYP/IEFPCM) calculated compositions of selected highest occupied and lowest unoccupied molecular orbitals of studied compounds in dichloromethane, expressed in terms of composing fragments (X - I (for 1 and 3) or $\mathrm{Br}\left(\mathbf{2}\right.$ and 4); $\mathrm{L}_{\mathrm{B}}$-bidentate ligand: $\mathrm{PhS}_{2}$ (1 and 3 ) or $\mathrm{MePhS}_{2}(2$ and 4)).

\begin{tabular}{ccccc}
\hline Compound & MO & As & X & L $_{\mathbf{B}}$ \\
\hline $\mathbf{1}$ & LUMO + 1 & 64 & 2 & 34 \\
& LUMO & 47 & 30 & 23 \\
& HOMO & 3 & 16 & 81 \\
& HOMO - 1 & 0 & 18 & 82 \\
& HOMO - 2 & 10 & 84 & 6 \\
\hline $\mathbf{2}$ & LUMO + & 48 & 3 & 49 \\
& LUMO + 1 & 69 & 1 & 30 \\
& LUMO & 46 & 27 & 27 \\
& HOMO & 3 & 11 & 86 \\
& HOMO - 1 & 0 & 5 & 95 \\
\hline 3 & LUMO + 1 & 64 & 2 & 34 \\
& LUMO & 48 & 29 & 23 \\
& HOMO & 2 & 15 & 83 \\
& HOMO - 1 & 0 & 15 & 6 \\
\hline 4 & HOMO - 2 & 10 & 84 & 49 \\
& LUMO + 2 & 48 & 3 & 29 \\
& LUMO + 1 & 69 & 2 & 26 \\
& LUMO & 47 & 27 & 88 \\
& HOMO & 3 & 9 & 95 \\
\hline
\end{tabular}

In the ${ }^{13} \mathrm{C}$ NMR spectra of $\mathbf{1}$ and $\mathbf{2}$ the signals related to the benzene ring appear as three of six peaks. The higher number of these signals for $\mathbf{3}$ and $\mathbf{4}$ is due to the presence of the methyl group on the aromatic ring, which causes all carbons to become magnetically unequivalent. Similarly, the aromatic protons give two (without $\mathrm{CH}_{3}$ group) or three signals in the ${ }^{1} \mathrm{H}$ NMR spectra. The $\mathrm{CH}_{3}$ group is found upfield at 2.4 and $20.8 \mathrm{ppm}$ in the ${ }^{1} \mathrm{H}$ and ${ }^{13} \mathrm{C}$ NMR spectra, respectively. All registered NMR spectra are shown in Figures S9-S12. 


\subsection{Cytotoxicity}

Arsenic trioxide induces apoptosis not only in APL cells [32] but also in many cancer cell lines, such as solid cancer cells like ovarian, esophageal, and prostate carcinomas [33-35]. There are also many other $\mathrm{As}_{2} \mathrm{O}_{3}$ sensitive cancer cells, for example small cell lung carcinoma [36], gastric cancer [37], neuroblastoma [38], multiple myeloma [39] and non-APL hematologic malignancies [40]. However, $\mathrm{As}_{2} \mathrm{O}_{3}$ is mainly applied in APL treatment where complete remission is observed in $85-93 \%$ patients. The disadvantages in arsenic treatment are its side effects; nevertheless they are usually mild and can be resolved with the appropriate symptomatic treatment or with reduction of $\mathrm{As}_{2} \mathrm{O}_{3}$ dose [32].

In clinical practice the administration of $\mathrm{As}_{2} \mathrm{O}_{3}$ to patients with APL could cause changes associated with an abnormal heart rhythm, which manifests from prolongation of the QT interval on an electrocardiogram diagram [41-43]. The study in a mouse model confirmed that arsenic used in concentrations comparable to those applied in humans causes myocardial apoptosis. Analysis of the myocardial function showed that $\mathrm{As}_{2} \mathrm{O}_{3}$ contributes to functional changes in the heart and were accompanied by cardiomyopathy, as determined by histopathological and ultrastructural examination [44].

An important accept of these arsenic complexes should be their comparative mode of action to $\mathrm{As}_{2} \mathrm{O}_{3}$, which would have a smaller influence on myocardial function. In our studies we examined the potency of arsenic(III) compounds 1-4, and arsenic trioxide as an anticancer reference agent, on cell growth of acute promyelocytic leukemia cells, NB4. As shown in Figure 9, all compounds as well as $\mathrm{As}_{2} \mathrm{O}_{3}$ induced cytotoxicity in a time and dose-dependent manner. Our results demonstrate that the viability of the cells treated with compounds 1-4 is higher than the viability of cells exposed for $\mathrm{As}_{2} \mathrm{O}_{3}$. Furthermore, based on the cytotoxicity data obtained, after $48 \mathrm{~h}$ treatment of the cancer cells, the $\mathrm{IC}_{50}$ values were determined. In comparison to the literature, the NB4 cells are relatively sensitive toward $\mathrm{As}_{2} \mathrm{O}_{3}$. Moreover, the estimated $\mathrm{IC}_{50}$ value $(1.43 \mu \mathrm{M})$ is below clinically tolerable doses [36] (Table 5). Our synthesized anticancer agents 1-4 exhibited lower cytotoxicity (about 7-fold lower for compounds 1-2 and nearly 28-fold lower for compounds 3-4) in comparison to arsenic trioxide. The differences of NB4 cells in sensitivity to synthesized compounds and $\mathrm{As}_{2} \mathrm{O}_{3}$ could be explained by their structural differences. The addition of a methyl group to the benzene ring (3-4 molecules) causes lower reduction in viability of promyelocytic leukemia cells in comparison to compounds 1-2. Moreover, the presence of $\mathrm{Br}^{-}$or $\mathrm{I}^{-}$anions in the structures did not influence the cytotoxicity. However, all newly prepared dithiolato arsenic(III) compounds inhibited cell proliferation, which is important for future investigations of potential applications in radionuclide cancer therapy. Research of these compounds creates new possibilities to connect arsenic with targeting biomolecules and apply similar compounds for nuclear medicine using radioactive arsenic isotopes.

Table 5. Concentrations of different anti-cancer agents that inhibit 50\% of NB4 cell growth, after $48 \mathrm{~h}$ of treatment.

\begin{tabular}{cc}
\hline Compound & IC $_{\mathbf{5 0}}[\boldsymbol{\mu M}]$ \\
\hline $\mathrm{As}_{2} \mathrm{O}_{3}$ & $1.43 \pm 0.07$ \\
$\mathbf{1}$ & $10.05 \pm 0.31$ \\
$\mathbf{2}$ & $10.28 \pm 0.17$ \\
$\mathbf{3}$ & $39.71 \pm 0.15$ \\
$\mathbf{4}$ & $39.87 \pm 0.08$ \\
\hline
\end{tabular}



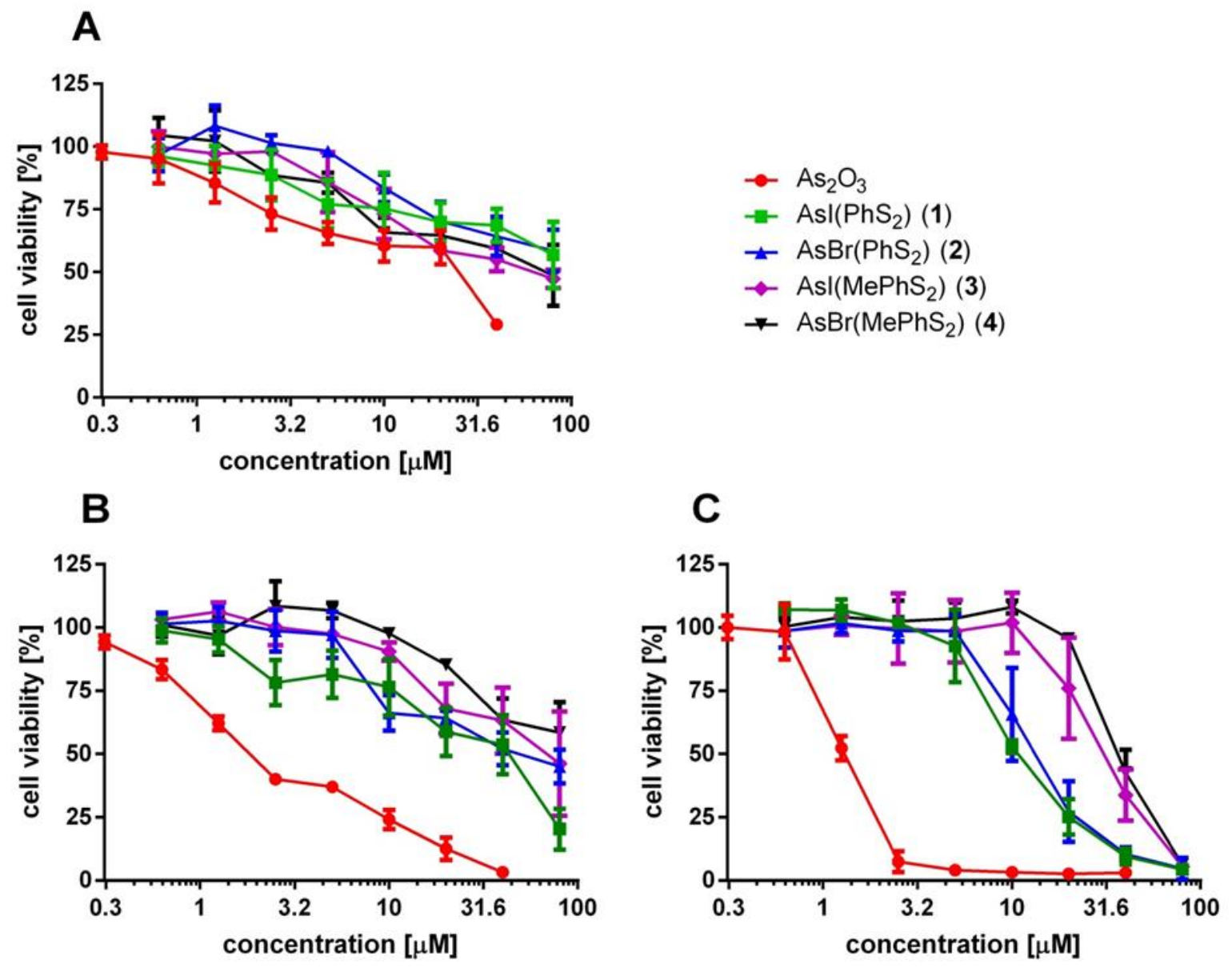

Figure 9. The results of cytotoxicity studies performed on NB4 cells with the use of dithiolato arsenic(III) compounds and $\mathrm{As}_{2} \mathrm{O}_{3}$ after $8 \mathrm{~h}(\mathrm{~A}), 24 \mathrm{~h}(\mathrm{~B})$ and $48 \mathrm{~h}(\mathrm{C})$ of treatment. The data points represent mean \pm standard deviation of three independent experiments. Statistical significance was considered when $p<0.05$ (image B for compound 2,3), $p<0.01$ (image B for compound 4).

\section{Materials and Methods}

All chemicals and solvents used were purchased from commercial sources. Elemental analyses were performed on an Elementar Vario EL III analyzer (Hanau, Germany). UV-Vis spectra in $\mathrm{CH}_{2} \mathrm{Cl}_{2}$ solutions were measured on a Thermo Scientific Evolution 600 spectrometer (Madison, WI, USA). Infrared absorption spectra in the range $4000-370 \mathrm{~cm}^{-1}$ at a resolution of $2 \mathrm{~cm}^{-1}$ were registered with a Thermo Scientific Nicolet iS10 FT-IR spectrometer (Madison, WI, USA) using KBr pellets. ${ }^{1} \mathrm{H}$ and ${ }^{13} \mathrm{C}$ NMR spectra using $\mathrm{CDCl}_{3}$ as a solvent were recorded with a Varian Unity Plus $500 \mathrm{MHz}$ spectrometer (Palo Alto, CA, USA). ESI-MS spectra were recorded with an Agilent Technologies 6530 Accurate-Mass Q-TOF LC/MS device (Santa Clara, CA, USA) equipped with a Zorbax Extend-C18 column $(2.1 \times 50 \mathrm{~mm}, 1.8 \mu \mathrm{m})$ working with a gradient of $5-100 \%$ acetonitrile within $3.5 \mathrm{~min}$ and a flow rate of $0.6 \mathrm{~mL} / \mathrm{min}$. High-performance liquid chromatography (HPLC) was performed using ELITE LaChrom (Hitachi, Tokyo, Japan) system with an L-2310 pump coupled to L-2455 diode array detector and L-2350 column oven. An Aeris Peptide column (3.6u XB-C18 $150 \times 4.6 \mathrm{~mm})$ eluting at a flow rate of $1 \mathrm{~mL} / \mathrm{min}$ was used. The gradient elution system contained $0.1 \%$ trifluoroacetic acid in deionized water (eluent A) and acetonitrile (eluent B). The gradient started with $95 \% \mathrm{~A} / 5 \% \mathrm{~B}$ for $5 \mathrm{~min}$; this was increased to $100 \% \mathrm{~B}$ over the next $15 \mathrm{~min}$ and held at $100 \% \mathrm{~B}$ for an additional $10 \mathrm{~min}$. Then, the gradient parameters were returned to the initial conditions over the $5 \mathrm{~min}$. HPLC grade solvents were degassed by ultrasonification for about $20 \mathrm{~min}$ just before use in chromatography measurements. 


\subsection{Preparation of the Complexes}

All complexes were prepared in a similar way by the methods described in [25]. To $1 \mathrm{mmol}$ of ligand (1,2-benzenedithiol or toluene-3,4-dithiol) dissolved in $\mathrm{CHCl}_{3}$ saturated with nitrogen, an equimolar amount of arsenic(III) compound $\left(\mathrm{AsBr}_{3}\right.$ or $\left.\mathrm{AsI}_{3}\right)$ was added. The reaction mixture was heated and stirred under reflux for $5 \mathrm{~h}$. Next, the solution was concentrated under reduced pressure and placed in a fridge. The crystals of each compound were isolated from the reaction mixture after a week.

\subsubsection{Iodo-(benzene-1,2-dithiolato-S,S')-arsenic(III)-AsI $\left(\mathrm{PhS}_{2}\right)(\mathbf{1})$}

Yield: 0.163 g (47.7\%). Anal. calc. for $\mathrm{C}_{6} \mathrm{H}_{4} \mathrm{~S}_{2}$ AsI: C, 21.07; $\mathrm{H}, 1.18 ; \mathrm{S}, 18.75$; found $\mathrm{C}, 21.08 ; \mathrm{H}$, 1.18; S $18.8 \%$. UV-Vis $\left(\mathrm{CH}_{2} \mathrm{Cl}_{2}\right) \lambda_{\max } / \mathrm{nm}\left(\varepsilon / \mathrm{M}^{-1} \cdot \mathrm{cm}^{-1}\right): 370(6000)$. IR $(\mathrm{KBr}) v_{\max } / \mathrm{cm}^{-1}: 1443 \mathrm{w}, 1421 \mathrm{~m}$, $1248 \mathrm{w}, 1135 \mathrm{w}, 933 \mathrm{w}, 846 \mathrm{w}, 741 \mathrm{vs}, 660 \mathrm{w}, 465 \mathrm{w}, 429 \mathrm{w}, 407 \mathrm{w}, 390 \mathrm{~s} .{ }^{1} \mathrm{H}$ NMR $\left(500.20 \mathrm{MHz}, \mathrm{CDCl}_{3}\right) \delta / \mathrm{ppm}$ $=7.59(\mathrm{dd}, J=6.0,3.0 \mathrm{~Hz}, 2 \mathrm{H}, \mathrm{Ar}-\mathrm{H}), 7.24(\mathrm{dd}, J=6.0,3.5 \mathrm{~Hz}, 2 \mathrm{H}, \mathrm{Ar}-\mathrm{H}) .{ }^{13} \mathrm{C}$ NMR $(125.79 \mathrm{MHz}$, $\left.\mathrm{CDCl}_{3}\right) \delta / \mathrm{ppm}=140.92(2 \mathrm{C}, \mathrm{Ar}), 127.18(2 \mathrm{C}, \mathrm{Ar}), 126.23(2 \mathrm{C}, \mathrm{Ar}) . \mathrm{ESI}-\mathrm{MS} \mathrm{m} / \mathrm{z}=214.8966[\mathrm{M}-\mathrm{I}+\mathrm{H}]^{+}$ (calc. 214.8965). HPLC $R_{t}=9.7$ min.

\subsubsection{Bromo-(benzene-1,2-dithiolato-S, $\left.\mathrm{S}^{\prime}\right)$-arsenic(III)- $\mathrm{AsBr}\left(\mathrm{PhS}_{2}\right)$ (2)}

Yield: $0.122 \mathrm{~g}(41.3 \%)$. Anal. calc. for $\mathrm{C}_{6} \mathrm{H}_{4} \mathrm{~S}_{2} \mathrm{AsBr}$ : C, 24.42; $\mathrm{H}, 1.37$; $\mathrm{S}, 21.74$; found $\mathrm{C}, 24.47$; $\mathrm{H}, 1.35 ; \mathrm{S}, 21.75 \%$. UV-Vis $\left(\mathrm{CH}_{2} \mathrm{Cl}_{2}\right) \lambda_{\max } / \mathrm{nm}\left(\varepsilon / \mathrm{M}^{-1} \cdot \mathrm{cm}^{-1}\right): 331$ (4150). IR (KBr) $v_{\max } / \mathrm{cm}^{-1}: 1445 \mathrm{~m}$, 1422m, 1250w, 1135w, 1106w, 934w, 742vs, 661w, 467w, 429w, 409w, 396m. ${ }^{1} \mathrm{H}$ NMR $(500.20 \mathrm{MHz}$, $\left.\mathrm{CDCl}_{3}\right) \delta / \mathrm{ppm}=7.62(\mathrm{dd}, J=5.5,3.3 \mathrm{~Hz}, 2 \mathrm{H}, \mathrm{Ar}-\mathrm{H}), 7.24(\mathrm{dd}, J=6.0,3.5 \mathrm{~Hz}, 2 \mathrm{H}, \mathrm{Ar}-\mathrm{H}) .{ }^{13} \mathrm{C}$ NMR $\left(125.79 \mathrm{MHz}, \mathrm{CDCl}_{3}\right) \delta / \mathrm{ppm}=139.92(2 \mathrm{C}, \mathrm{Ar}), 127.01$ (2C, Ar), 126.20 (2C, Ar). ESI-MS m/z = 214.8966 $[\mathrm{M}-\mathrm{Br}+\mathrm{H}]^{+}$(calc. 214.8965). HPLC $\mathrm{R}_{\mathrm{t}}=9.7 \mathrm{~min}$.

\subsubsection{Iodo-(toluene-3,4-dithiolato-S,S')-arsenic(III)-AsI $\left(\mathrm{MePhS}_{2}\right)$ (3)}

Yield: $0.207 \mathrm{~g}(56.7 \%)$. Anal. calc. for $\mathrm{C}_{7} \mathrm{H}_{6} \mathrm{~S}_{2}$ AsI: C, 23.61; $\mathrm{H}, 1.70$; S, 18.01; found C, 23.76; $\mathrm{H}, 1.74$; S $18.00 \%$. UV-Vis $\left(\mathrm{CH}_{2} \mathrm{Cl}_{2}\right) \lambda_{\max } / \mathrm{nm}\left(\varepsilon / \mathrm{M}^{-1} \cdot \mathrm{cm}^{-1}\right): 375(6300)$. IR $(\mathrm{KBr}) v_{\max } / \mathrm{cm}^{-1}: 1459 \mathrm{~m}, 1380 \mathrm{w}$, 1253w, 855w, 805vs, 693w, 684w, 637w, 536m, 486w, 448m, 427w, 400m, 398m. ${ }^{1} \mathrm{H}$ NMR $(500.20 \mathrm{MHz}$, $\left.\mathrm{CDCl}_{3}\right) \delta / \mathrm{ppm}=7.47(\mathrm{~d}, J=8.0 \mathrm{~Hz}, 1 \mathrm{H}, \mathrm{Ar}-\mathrm{H}), 7.40(\mathrm{~s}, 1 \mathrm{H}, \mathrm{Ar}-\mathrm{H}), 7.05(\mathrm{~d}, J=8.5 \mathrm{~Hz}, 1 \mathrm{H}, \mathrm{Ar}-\mathrm{H}), 2.37$ $\left(\mathrm{s}, 3 \mathrm{H}, \mathrm{CH}_{3}\right) .{ }^{13} \mathrm{C}$ NMR $\left(125.79 \mathrm{MHz}, \mathrm{CDCl}_{3}\right) \delta / \mathrm{ppm}=141.10$ (1C, Ar), 137.63 (1C, Ar), 136.59 (1C, Ar), 127.50 (1C, Ar), 127.40 (1C, Ar), 126.76 (1C, Ar), 20.80 (1C, $\left.\mathrm{CH}_{3}\right)$. ESI-MS m/z = $228.9121[\mathrm{M}-\mathrm{I}+\mathrm{H}]^{+}$ (calc. 228.9121). HPLC $R_{t}=10.3 \mathrm{~min}$.

\subsubsection{Bromo-(toluene-3,4-dithiolato-S, $\left.\mathrm{S}^{\prime}\right)$-arsenic(III)- $\mathrm{AsBr}\left(\mathrm{MePhS}_{2}\right)$ (4)}

Yield: $0.124 \mathrm{~g}(40.1 \%)$. Anal. calc. for $\mathrm{C}_{7} \mathrm{H}_{6} \mathrm{~S}_{2} \mathrm{AsBr}$ : C, 27.20; $\mathrm{H}, 1.96$; S, 20.75; found C, 27.20; $\mathrm{H}, 1.97 ; \mathrm{S} 20.80 \%$. UV-Vis $\left(\mathrm{CH}_{2} \mathrm{Cl}_{2}\right) \lambda_{\max } / \mathrm{nm}\left(\varepsilon / \mathrm{M}^{-1} \cdot \mathrm{cm}^{-1}\right): 336(4200)$. IR $(\mathrm{KBr}) \gamma_{\max } / \mathrm{cm}^{-1}: 2912 \mathrm{w}$ br, $1460 \mathrm{~m}, 1381 \mathrm{w}, 1254 \mathrm{w}, 856 \mathrm{w}, 806 \mathrm{vs}, 536 \mathrm{w}, 486 \mathrm{w}, 449 \mathrm{~m}, 428 \mathrm{w}, 403 \mathrm{~m}, 398 \mathrm{w} .{ }^{1} \mathrm{H}$ NMR $(500.20 \mathrm{MHz}$, $\left.\mathrm{CDCl}_{3}\right) \delta / \mathrm{ppm}=7.48(\mathrm{~d}, J=8.0 \mathrm{~Hz}, 1 \mathrm{H}, \mathrm{Ar}-\mathrm{H}), 7.42(\mathrm{~s}, 1 \mathrm{H}, \mathrm{Ar}-\mathrm{H}), 7.05(\mathrm{~d}, J=8.0 \mathrm{~Hz}, 1 \mathrm{H}, \mathrm{Ar}-\mathrm{H}), 2.37$ $\left(\mathrm{s}, 3 \mathrm{H}, \mathrm{CH}_{3}\right) .{ }^{13} \mathrm{C} \mathrm{NMR}\left(125.79 \mathrm{MHz}, \mathrm{CDCl}_{3}\right) \delta / \mathrm{ppm}=140.07$ (1C, Ar), $136.60(1 \mathrm{C}, \mathrm{Ar}), 136.57$ (1C, Ar), 127.38 (1C, Ar), 127.32 (1C, Ar), $126.60(1 \mathrm{C}, \mathrm{Ar}), 20.77\left(1 \mathrm{C}, \mathrm{CH}_{3}\right) . \mathrm{ESI}-\mathrm{MS} \mathrm{m} / \mathrm{z}=228.9121[\mathrm{M}-\mathrm{Br}+\mathrm{H}]^{+}$ (calc. 228.9121). HPLC $R_{t}=10.4$ min.

\subsection{X-ray Crystallography}

Diffraction data of suitable single crystals of studied arsenic(III) compounds were collected at $100 \mathrm{~K}$ on a Rigaku SuperNova (dual source) four circle diffractometer equipped with an Eos CCD detector (Oxford, UK). The measurements were performed using a mirror-monochromated Mo or $\mathrm{Cu}$ $\mathrm{K} \alpha$ radiation $(\lambda=0.71073$ or $1.54184 \AA$ ) from a microfocus Mova or Nova X-ray source, respectively. All required procedures including data collection, data reduction and multi-scan absorption corrections were performed using CrysAlis PRO software (version 1.171.38.41, Oxford, UK). The structures 
were solved by direct methods and refined by the full matrix least-squares technique on $\mathrm{F}^{2}$ data. All non-hydrogen atoms were refined anisotropically while the hydrogen atoms were placed in calculated positions and refined isotropically using standard parameters. All calculations were performed using SHELX programs [45] integrated with the OLEX2 crystallographic software [46]. The MERCURY program [47] was applied for graphical representation of the crystal structures. Selected crystallographic parameters and refinement details are presented in Table 2.

\subsection{Computational Details}

The structures obtained for arsenic(III) compounds from the X-ray measurements were used as the initial geometries in the optimization of their molecular structures. The ground-state geometries of these complexes were modeled using the DFT method with B3LYP hybrid functional $[48,49]$. The results obtained for a few different double- and triple- $\zeta$ valence basis sets were collected and compared (Tables S1-S4). The LANL2DZ basis set [50] was applied for iodine atom when using double- $\zeta$ valence basis sets. Vibrational frequency calculations were performed to verify the minimum energy states. The calculated harmonic frequencies were scaled by 0.97 . Based on optimized structures, time-dependent DFT [51] calculations with the B3LYP functional and $6-31+G(d, p)$ basis set including the LANL2DZ basis set for an iodine atom were carried out to obtain absorption spectra. The solvent effect of dichloromethane was modeled using the polarizable continuum model (IEFPCM) [52]. All calculations were carried out with the Gaussian 09 program package [53]. The GaussView 5.0 [53] and GaussSum 3.0 [54] programs were employed for visualization of the molecular orbitals and determination of the percent contributions of atoms and atom groups to each of the MOs.

\subsection{Cytotoxicity Studies}

Human acute promyelocytic leukemia cells, NB4 (purchased from DSMZ company, Braunschweig, Germany) were cultured in RPMI 1640 Medium (Biological Industries, Beit-Haemek, Israel), supplemented with $10 \%$ of FBS (Biological Industries, Israel) and $1 \%$ of antibiotics (Biological Industries, Israel) at $37^{\circ} \mathrm{C}$ in a humidified atmosphere of $5 \% \mathrm{CO}_{2}$ in the air. The effects of new potential cytotoxic drugs on cell viability were determined by MTS assay as previously described [55]. Briefly, the cells were seeded in 96-well plates ( 3000 cells/well) and incubated over-night at $37^{\circ} \mathrm{C}$ in $5 \% \mathrm{CO}_{2}$. After $24 \mathrm{~h}$, the cells were treated with compounds 1-4 at different concentrations varied from 0.625 to $80 \mu \mathrm{M}$. $\mathrm{As}_{2} \mathrm{O}_{3}$ was used as a reference compound. After $8 \mathrm{~h}, 24 \mathrm{~h}$ and $48 \mathrm{~h}$ of incubation, $20 \mu \mathrm{L}$ aliquots of MTS solution (CellTiter $96^{\circledR}$ AQueous reagent, Promega, Mannheim, Germany) were added to each well and re-incubated for $2 \mathrm{~h}$ at $37^{\circ} \mathrm{C}$. Then, the absorbance was measured at $492 \mathrm{~nm}$, on microplate reader (Apollo-1, LB913, Berthold, Bad Wildbad, Germany). The percentage of cell viability was calculated from the control group. All treatments were conducted in sixplicate and the experiments were repeated thrice.

\subsection{Statistical Analysis}

The cytotoxicity experiments (MTS assay) were performed at least in triplicate. To assess the differences between compounds $\mathbf{1}-\mathbf{4}$ and control $\left(\mathrm{As}_{2} \mathrm{O}_{3}\right)$ one-way analysis of variance (ANOVA), followed by Dunnett's multiple comparisons test was applied. Statistical analysis was performed using GraphPad Prism 8.0 software (GraphPad Software Inc., San Diego, CA, USA). Data were presented as mean \pm standard deviation (SD) and the results were considered statistically significant when $p$-value was $<0.05$.

\section{Conclusions and Summary}

In this work four new arsenic(III) complexes (1-4) with heavy halide ions (bromide and iodide) and two dithiolato ligands derived from 1,2-benzenedithiol and toluene-3,4-dithiol were synthesized and characterized using conventional physico-chemical methods. Among the compounds obtained, the $\mathrm{AsBr}\left(\mathrm{PhS}_{2}\right)$ complex (2) has a structure with a rare 13 molecules in the asymmetric 
unit. The complexes 1 and 2 possessing the 1,2-benzenedithiolato ligand exhibited, after $48 \mathrm{~h}$ of treatment, 4-fold higher in vitro cytotoxicity $\left(\mathrm{IC}_{50} \approx 10 \mu \mathrm{M}\right)$ toward human acute promyelocytic leukemia cancer cells (NB4) than compounds 3 and 4 with toluene-3,4-dithiolato ligand ( $\mathrm{IC}_{50} \approx 40 \mu \mathrm{M}$ ). The replacement of an iodide anion with a bromide anion in the studied complexes does not affect the change in their toxicity. Although their toxicity is lower compared to $\mathrm{As}_{2} \mathrm{O}_{3}\left(\mathrm{IC}_{50}=1.4 \mu \mathrm{M}\right)$, a popular chemotherapeutic agent, it still seems to be suitable for cancer treatment. The studies presented show that prepared compounds are potentially promising anticancer agents worthy of further investigation. The huge advantage of the studied compounds is also the possibility of exchanging stable arsenic for radioisotope ${ }^{77} \mathrm{As}$, which could significantly increase the therapeutic effect, especially since there is a strong synergistic effect between chemo and radiotherapy [56].

Supplementary Materials: CCDC 1948452-1948455 contain the supplementary crystallographic data for this paper. These data can be obtained free of charge from the CCDC via http://www.ccdc.cam.ac.uk/data_request/cif. The other Supplementary Materials are available online at http://www.mdpi.com/1420-3049/24/21/3865/s1: Tables S1-S4: Comparison of the experimentally obtained and calculated (DFT/B3LY P/6-31+G(d,p);LANL2DZ for I) bond lengths and angles for compounds 1-4 (MAD means the mean absolute deviation), Figure S1: IR spectrum of 1,2-benzenedithiol $\left(\mathrm{Ph}(\mathrm{SH})_{2}\right)$, Figure S2. IR spectrum of AsI $\left(\mathrm{PhS}_{2}\right)$ (1), Figure S3: IR spectrum of $\mathrm{AsBr}\left(\mathrm{PhS}_{2}\right)(\mathbf{2})$, Figure S4: IR spectrum of toluene-3,4-dithiol $\left(\mathrm{MePh}(\mathrm{SH})_{2}\right)$, Figure S5: IR spectrum of AsI $\left(\mathrm{MePhS}_{2}\right)$ (3), Figure S6: IR spectrum of AsBr( $\left.\mathrm{MePhS}_{2}\right)$ (4), Figure S7: Experimental (black line) and TD-DFT simulated (red vertical lines) UV-Vis absorption spectra of the studied complexes in $\mathrm{CH}_{2} \mathrm{Cl}_{2}$ solution, Figure S8: Unoccupied and occupied orbital contours relative to the lower energy transitions for compounds 1-4, Tables S5-S8: Calculated transitions for compounds 1-4, Figure S9: (a) ${ }^{1} \mathrm{H}$ NMR and (b) ${ }^{13} \mathrm{C}$ NMR spectra of $\mathrm{AsI}\left(\mathrm{PhS}_{2}\right)$ (1), Figure S10: (a) ${ }^{1} \mathrm{H}$ NMR and (b) ${ }^{13} \mathrm{C}$ NMR spectra of AsBr(PhS 2 ) (2), Figure S11: (a) ${ }^{1} \mathrm{H}$ NMR and (b) ${ }^{13} \mathrm{C}$ NMR spectra of AsI $\left(\mathrm{MePhS}_{2}\right)(3)$, Figure S12: (a) ${ }^{1} \mathrm{H}$ NMR and (b) ${ }^{13} \mathrm{C}$ NMR spectra of $\mathrm{AsBr}\left(\mathrm{MePhS}_{2}\right)$ (4).

Author Contributions: M.L. designed the experiments and conducted syntheses; K.L. and M.L. studied the physico-chemical properties of compounds; K.L. performed DFT calculations and structural studies; A.M.-P. and M.L. carried out the biological studies; M.L., K.L., A.M.-P. and A.B. analyzed the data; M.L. and K.L. wrote the paper.

Funding: This work was supported from the statutory research by the Institute of Nuclear Chemistry and Technology. Calculations were supported by PL-Grid Infrastructure (grant ID: magdalenka).

Conflicts of Interest: The authors declare no conflict of interest.

\section{References and Notes}

1. Florea, A.M.; Yamoah, E.N.; Dopp, E. Intracellular calcium disturbs induced by arsenic and its met hylated derivatives in relation to genomic damage and apoptosis induction. Environ. Health Perspect. 2005, 113, 659-664. [CrossRef] [PubMed]

2. Miller, W.H.; Schipper, H.M.; Lee, J.S.; Singer, J.; Waxman, S. Mechanisms of Action of Arsenic Trioxide. Cancer Res. 2002, 62, 3893-3903. [PubMed]

3. Hughes, M.F. Arsenic toxicity and potential mechanisms of action. Toxicol. Lett. 2002, 133, 1-16. [CrossRef]

4. Johnson, J.M.; Voegtin, C. Arsenic Derivatives of Cysteine. J. Biol. Chem. 1930, 89, 27-31.

5. Ochi, T.; Kaise, T.; Oya-Ohta, Y. Glutathione plays different roles in the induction of the cytotoxic effects of inorganic and organic arsenic compounds in cultured BALB/c 3 T3 cells. Experientia 1994, 50, 115-120. [CrossRef]

6. Delnomdedieu, M.; Basti, M.M.; Otvos, J.D.; Thomas, D.J. Reduction and binding of arsenate and dimethylarsinate by gluthation: a magnetic resonance study. Chem.- Biol. Int. 1994, 90, 139-155. [CrossRef]

7. Yang, C.-H.; Kuo, M.-L.; Chen, J.-C.; Chen, Y.-C. Arsenic trioxide sensitivity is associated with low level of glutathione in cancer cells. Br. J. Cancer 1999, 81, 796-799. [CrossRef]

8. Cea-Olivares, R.; Toscano, R.A.; Lopez, M.; Garcia, P. Coordination ability of the heterocycles 1,3-dithia-2-arsaand -stiba-cyclopentanes towards sulfur containing ligands, Part II. Diheterocyclic dithiocarbamate complexes. X-ray structure of the 4-morpholinecarbodithioate of 1,3-dithia-2-arsa-cyclopentane. Monatsh. Chem. 1993, 124, 177-183. [CrossRef]

9. Garje, S.S.; Jain, V.K.; Tiekink, E.R.T. Synthesis and characterisation of organoarsenic(III) xanthates and dithiocarbamates. X-ray crystal structures of $\mathrm{RAs}\left(\mathrm{S}_{2} \mathrm{CNEt}_{2}\right)_{2}, \mathrm{R}=\mathrm{Me}$ and Ph. J. Organomet. Chem. 1997, 538, 129-134. [CrossRef] 
10. Wenclawiak, B.W.; Uttich, S.; Deiseroth, H.J.; Schmitz, D. Studies on bulky residual group substituted arsenic(III) dithiocarbamate structures. Inorg. Chim. Acta 2003, 348, 1-7. [CrossRef]

11. Chen, D.; Lai, C.S.; Tiekink, E.R.T. Tris(N,N-dimethyldithiocarbamato)arsenic(III) dichloromethane solvate. Appl. Organomet. Chem. 2003, 17, 813-814. [CrossRef]

12. Liu, Y.; Tiekink, E.R.T. Crystal structure of tris(pyrrolinedithiocarbamato)arsenic(III), $\mathrm{As}\left[\mathrm{S}_{2} \mathrm{CN}\left(\mathrm{CH}_{2}\right)_{4}\right]_{3} . \mathrm{Z}$. Kristallogr. -New Cryst. Struct. 2005, 220, 339-341. [CrossRef]

13. Chauhan, H.P.S.; Kori, K.; Shaik, N.M.; Mathur, S.; Huch, V. Dialkyldithiocarbamate derivatives of toluene-3,4-dithiolato arsenic(III) and -bismuth(III): synthetic, spectral and single crystal X-ray structural studies. Polyhedron 2005, 24, 89-95. [CrossRef]

14. Li, F.; Yin, H.; Zhai, J.; Wang, D. Tris $\left(N, N\right.$-diethylcarbamato- $\left.\kappa^{2} S, S^{\prime}\right)$ arsenic(III). Acta Crystallogr. E 2006, 62, m2205-m2207. [CrossRef]

15. Hoskins, B.F.; Tiekink, E.R.T.; Winter, G. Structural features of group V A xanthates. The crystal and molecular structures of tris(O-isopropylxanthato-arsenic(III), -antimony(III) and -bismuth(III). Inorg. Chim. Acta 1985, 99, 177-182. [CrossRef]

16. Burford, N.; Parks, T.M.; Royan, B.W.; Borecka, B.; Cameron, T.S.; Richardson, J.F.; Gabe, E.J.; Hynes, R. Aza- and thiaarsolidinium cations: novel structural features for carbene analogues. J. Am. Chem. Soc. 1992, 114, 8147-8153. [CrossRef]

17. Shaikh, T.A.; Bakus, R.C., II; Parkin, S.; Atwood, D.A. Structural characteristics of 2-halo-1,3,2-dithiarsenic compounds and tris-(pentafluorophenylthio)-arsen. J. Organomet. Chem. 2006, 691, 1825-1833. [CrossRef]

18. DeGraffenreid, A.J.; Feng, Y.; Wycoff, D.E.; Morrow, R.; Phipps, M.D.; Cutler, C.S.; Ketring, A.R.; Barnes, C.L.; Jurisson, S.S. Dithiol aryl arsenic compounds as potential diagnostic and therapeutic radiopharmaceuticals. Inorg. Chem. 2016, 55, 8091-8098. [CrossRef]

19. Lindquist, N.R.; Carter, T.G.; Cangelosi, V.M.; Zakharov, L.N.; Johnson, D.W. Three's company: co-crystallization of a self-assembled S4 metallacyclophane with two diastereomeric metallacycle intermediates. Chem. Commun. 2010, 46, 3505-3507. [CrossRef]

20. Pappalardo, G.C.; Chakravorty, R.; Irgolic, K.J.; Meyers, E.A. Tris(phenylthio)arsine, $\mathrm{C}_{18} \mathrm{H}_{15} \mathrm{AsS}_{3}$. Acta Crystallogr. C 1983, 39, 1618-1620. [CrossRef]

21. Carter, T.G.; Healey, E.R.; Pitt, M.A.; Johnson, D.W. Secondary bonding interactions observed in two arsenic thiolate complexes. Inorg. Chem. 2005, 44, 9634-9636. [CrossRef] [PubMed]

22. Cangelosi, V.M.; Pitt, M.A.; Vickaryous, W.J.; Allen, C.A.; Zakharov, L.N.; Johnson, D.W. Design considerations for the group 15 elements: The pnictogen $\cdots \pi$ interaction as a complementary component in supramolecular assembly design. Cryst. Growth Des. 2010, 10, 3531-3536. [CrossRef]

23. Ioannou, P.V.; Moushi, E.E. The crystal structure of tris(4-aminophenylthio)arsine, $\operatorname{As}\left(\mathrm{SC}_{6} \mathrm{H}_{4}-4-\mathrm{NH}_{2}\right)_{3}$. Main Group Chem. 2013, 12, 285-292.

24. Tran, T.T.P.; Ould, D.M.C.; Wilkins, L.C.; Wright, D.S.; Melen, R.L.; Rawson, J.M. Supramolecular aggregation in dithia-arsoles: chlorides, cations and N-centred paddlewheels. CrystEngComm 2017, 19, 4696-4699. [CrossRef]

25. Kisenyi, J.M.; Willey, G.R.; Drew, M.G.B.; Wandiga, S.O. Toluene-3,4-dithiol $\left(\mathrm{H}_{2} \mathrm{tdt}\right)$ complexes of group 5B halides. Observations of lone-pair stereochemical activity and redox behaviour. Crystal and molecular structures of $[\mathrm{AsCl}(\mathrm{tdt})]$ and $\left[\mathrm{PPh}_{4}\right]\left[\mathrm{Sb}(\mathrm{tdt})_{3}\right]$. J. Chem. Soc. Dalton Trans. 1985, 69-74. [CrossRef]

26. Wang, J.-J.; Kryatova, O.P.; Rybak-Akimova, E.V.; Holm, R.H. Comparative kinetics and mechanism of oxygen and sulfur atom transfer reactions mediated by bis(dithiolene) complexes of molybdenum and tungsten. Inorg. Chem. 2004, 43, 8092-8101. [CrossRef]

27. Maheshwari, S.; Bundela, K.; Ojha, K.G. Synthesis and spectroscopic characterization of toluene-3,4-dithiolatoarsenic(III)-O, $\mathrm{O}^{\prime}$-ditolyl/alkylene dithiophosphate compounds: crystal structure of $\left[\mathrm{CH}_{3} \mathrm{C}_{6} \mathrm{H}_{3} \mathrm{~S}_{2} \mathrm{As}\left\{\mathrm{S}_{2} \mathrm{P}\left(\mathrm{OC}_{6} \mathrm{H}_{4} \mathrm{Me}-m\right)_{2}\right\}\right]$. J. Coord. Chem. 2014, 67, 1088-1096. [CrossRef]

28. Ellison, P.A.; Barnhart, T.E.; Chen, F.; Hong, H.; Zhang, Y.; Theuer, C.P.; Cai, W.; Nickles, R.J.; DeJesus, O.T. High yield production and radiochemical isolation of isotopically pure arsenic-72 and novel radioarsenic labeling strategies for the development of theranostic radiopharmaceuticals. Bioconjug. Chem. 2016, 27, 179-188. [CrossRef]

29. Gonzalez-Montiel, S.; Andrade-Lopez, N.; Alvarado-Rodriguez, J.G. Synthesis, Characterisation and Properties of As-Monohalogenated Dibenzoarsocines $\mathrm{S}\left(\mathrm{C}_{6} \mathrm{H}_{4} \mathrm{~S}\right)_{2} \mathrm{AsHal}(\mathrm{Hal}=\mathrm{Cl}, \mathrm{Br}, \mathrm{I})-\mathrm{A}$ Study of the Transannular Interaction S $\rightarrow$ As. Eur. J. Inorg. Chem. 2006, 18, 3762-3768. [CrossRef] 
30. Mantina, M.; Chamberlin, A.C.; Valero, R.; Cramer, C.J.; Truhlar, D.G. Consistent van der Waals radii for the whole main group. J. Phys. Chem. A 2009, 113, 5806-5812. [CrossRef]

31. CSD codes: $Z^{\prime}=13$ - NEHKUJ.; $Z^{\prime}=14$ - GEQLUM04, OFUVUJ, OGUROZ01; $Z^{\prime}=15-$ NABUOX.; $Z^{\prime}=16$ BIPCOS01, CHOEST01, CHOLES03, JIZFAB, LANBOS, NIJCER, NIKZUC, PUBMUU21, PUTKOE, UNADOD, VANFUO, VANJAY, VIXQOK, ZEFHEA.; Z'=17 - KEFSUM.; Z'=18 - HUVLAL, KETTUB, ZZZVXQ06; Z'=19 - HUGDOC.; Z'=20 - VUJBAE.; Z'=24 - IDOSID, OFEREZ, VIFXEQ.; Z'=32 - TMESNH.; Z'=56 - OGUROZ.

32. Wang, Z.-Y. Arsenic compound as anticancer agents. Cancer Chemother. Pharmacol. 2001, 48 (Suppl. 1), $72-76$. [CrossRef] [PubMed]

33. Maeda, H.; Hori, S.; Nishitoh, H.; Ichijo, H.; Ogawa, O.; Kakehi, Y.; Kakizuka, A. Tumor growth inhibition by arsenic trioxide $\left(\mathrm{As}_{2} \mathrm{O}_{3}\right)$ in the orthotopic metastasis model of androgen-independent prostate cancer. Cancer Res. 2001, 61, 5432-5440. [PubMed]

34. Shen, Z.Y.; Zhang, Y.; Chen, J.Y.; Chen, M.H.; Shen, J.; Luo, W.H.; Zeng, Y. Intratumoral injection of arsenic to enhance antitumor efficacy in human esophageal carcinoma cell xenografts. Oncol. Rep. 2004, 11, 155-159. [CrossRef] [PubMed]

35. Bornstein, J.; Sagi, S.; Haj, A.; Harroch, J.; Fares, F. Arsenic trioxide inhibits the growth of human ovarian carcinoma cell line. Gynecol. Oncol. 2005, 99, 726-729. [CrossRef]

36. Pettersson, H.M.; Pietras, A.; Munksgaard Persson, M.; Karlsson, J.; Johansson, L.; Shoshan, M.C.; Pahlman, S. Arsenic trioxide is highly cytotoxic to small cell lung carcinoma cells. Mol. Cancer Ther. 2009, 8, 160-170. [CrossRef]

37. Abudoureyimu, A.; Muhemaitibake, A. Arsenic trioxide regulates gastric cancer cell apoptosis by mediating cAMP. Eur. Rev. Med. Pharmacol. Sci. 2017, 21, 612-617.

38. Gesundheit, B.; Malach, L.; Or, R.; Hahn, T. Neuroblastoma Cell Death is Induced by Inorganic Arsenic Trioxide $\left(\mathrm{As}_{2} \mathrm{O}_{3}\right)$ and Inhibited by a Normal Human Bone Marrow Cell-Derived Factor. Cancer Microenviron. 2008, 1, 153-157. [CrossRef]

39. Munshi, N.C. Arsenic Trioxide: An Emerging Therapy for Multiple Myeloma. Oncologist 2001, 6 (Suppl. 2), $17-21$. [CrossRef]

40. Murgo, A.J. Clinical Trials of Arsenic Trioxide in Hematologic and Solid Tumors: Overview of the National Cancer Institute Cooperative Research and Development Studies. Oncologist 2001, 6 (Suppl. 2), 22-28. [CrossRef]

41. Zhou, J.; Meng, R.; Li, X.; Lu, C.; Fan, S.; Yang, B. The effect of arsenic trioxide on QT interval prolongation during APL therapy. Chin. Med. J. (Engl. ) 2003, 116, 1764-1766.

42. Siu, C.-W.; Au, W.-Y.; Yung, C.; Kumana, C.R.; Lau, C.-P.; Kwong, Y.-L.; Tse, H.-F. Effects of oral arsenic trioxide therapy on QT intervals in patients with acute promyelocytic leukemia: implications for long-term cardiac safety. Blood 2006, 108, 103-106. [CrossRef] [PubMed]

43. Barbey, J.T.; Pezzullo, J.C.; Soignet, S.L. Effect of arsenic trioxide on QT interval in patients with advanced malignancies. J. Clin. Oncol. 2003, 21, 3609-3615. [CrossRef] [PubMed]

44. Li, Y.; Sun, X.; Wang, L.; Zhou, Z.; Kang, Y.J. Myocardial toxicity of arsenic trioxide in a mouse model. Cardiovasc. Toxicol. 2002, 1, 63-73.

45. Sheldrick, G.M. Crystal structure refinement with SHELXL. Acta Crystallogr. C 2015, 71, 3-8. [CrossRef]

46. Dolomanov, O.V.; Bourhis, L.J.; Gildea, R.J.; Howard, J.A.K.; Puschmann, H. OLEX2: A complete structure solution, refinement and analysis program. J. Appl. Crystallogr. 2009, 42, 339-341. [CrossRef]

47. Macrae, C.F.; Bruno, I.J.; Chisholm, J.A.; Edgington, P.R.; McCabe, P.; Pidcock, E.; Rodriguez-Monge, L.; Taylor, R.; van de Streek, J.; Wood, P.A. Mercury CSD 2.0-New features for the visualization and investigation of crystal structures. J. Appl. Crystallogr. 2008, 41, 466-470. [CrossRef]

48. Lee, C.; Yang, W.; Parr, R.G. Development of the Colle-Salvetti correlation-energy formula into a functional of the electron density. Phys. Rev. B 1988, 37, 785-789. [CrossRef]

49. Becke, A.D. Density-functional thermochemistry. III. The role of exact exchange. J. Chem. Phys. 1993, 98, 5648-5652. [CrossRef]

50. Hay, P.J.; Wadt, W.R. Ab initio effective core potentials for molecular calculations. Potentials for K to Au including the outermost core orbitals. J. Chem. Phys. 1985, 82, 299-310. [CrossRef]

51. Adamo, C.; Jacquemin, D. The calculations of excited-state properties with Time-Dependent Density Functional Theory. Chem. Soc. Rev. 2013, 42, 845-856. [CrossRef] 
52. Cances, E.; Mennucci, B.; Tomasi, J. A new integral equation formalism for the polarizable continuum model: Theoretical background and applications to isotropic and anisotropic dielectrics. J. Chem. Phys. 1997, 107, 3032-3041. [CrossRef]

53. Frisch, M.J.; Trucks, G.W.; Schlegel, H.B.; Scuseria, G.E.; Robb, M.A.; Cheeseman, J.R.; Scalmani, G.; Barone, V.; Mennucci, B.; Petersson, G.A.; et al. Gaussian 09, Revision C.01; Gaussian, Inc.: Wallingford, CT, USA, 2010.

54. O’Boyle, N.M.; Tenderholt, A.L.; Langner, K.M. Software news and updates cclib: A library for package-independent computational chemistry algorithms. J. Comp. Chem. 2008, 29, 839-845. [CrossRef] [PubMed]

55. Majkowska-Pilip, A.; Rius, M.; Bruchertseifer, F.; Apostolidis, C.; Weis, M.; Bonelli, M.; Laurenza, M.; Królicki, L.; Morgenstern, A. In vitro evaluation of 225Ac-DOTA-Substance P for targeted alpha therapy of glioblastoma multiforme. Chem. Biol. Drug Design 2018, 92, 1344-1356. [CrossRef] [PubMed]

56. Yordanova, A.; Ahrens, H.; Feldmann, G.; Brossart, P.; Gaertner, F.C.; Fottner, C.; Weber, M.M.; Ahmadzadehfar, H.; Schreckenberger, M.; Miederer, M.; et al. Peptide Receptor Radionuclide Therapy Combined With Chemotherapy in Patients With Neuroendocrine Tumors. Clin. Nucl. Med. 2019, 44, e329-e335. [CrossRef]

Sample Availability: Sample Availability: Not available. 